\title{
Brain lesions in oncology patients: recognising metastatic versus non metastatic lesions
}

\author{
Philip Rich
}

From International Cancer Imaging Society Meeting and 15th Annual Teaching Course (ICIS 2015)

London, UK. 5-7 October 2015

Therapeutic developments across a range of primary tumours have resulted in more cancer patients with cerebral metastatic disease undergoing active management and imaging surveillance. There has been an increase in the caseload and range of disease presenting to oncology and neuro-oncology MDTs. In this lecture I will present examples of intracranial metastases, discuss differences in appearance according to primary site and tips for differentiating from primary intracranial tumours and non-neoplastic mimics.

Published: 2 October 2015

Submit your next manuscript to BioMed Central and take full advantage of:

- Convenient online submission

- Thorough peer review

- No space constraints or color figure charges

- Immediate publication on acceptance

- Inclusion in PubMed, CAS, Scopus and Google Scholar

- Research which is freely available for redistribution 